\title{
University English Teachers and Students' Perceptions of Language Choices in EFL Classroom
}

\author{
Rahmah Julianti \\ Haryanto Atmowardoyo \\ Murni Mahmud \\ rahmah.julianti@gmail.com
}

State University of Makassar, Indonesia

\begin{abstract}
This research deals with university English teachers' and the students' perceptions regarding language choices used in the EFL classroom. This research involved two English lecturers and thirty two second semester students of English education in STKIP YPUP Makassar. This research applied qualitative approach. The data were collected via observation, interview and recording. The data obtained were analyzed in three phases, namely data reduction, data display and conclusion or verification. The result of the research showed that the lecturers preferred employing bilingual approach with the ideal language choice was English tended to be used less than Indonesian in the classroom. They did have language choices for the classroom interaction in which English was considered as the right choice for the lecturers in asking students' feeling, praising, giving questions and directions as well as the students' response for specific category while Indonesian was for joking, using the students' idea, giving information, criticizing the students' behavior and the students' response for open-ended category. Surprisingly, the students' language choices for this classroom interaction indicated the same preferences. However, they considered monolingual as important thing in English class yet still thought the need of Indonesian in which language rule was needed to apply. As a whole, they demanded more English exposure in the classroom interaction with inevitable allowance of Indonesian.
\end{abstract}

Key words: Language choices, Perceptions, EFL classroom

\section{INTRODUCTION}

EFL context situates the use of target language in the classroom essential for very limited access outside the classroom. However, with the struggle of target language use, there is undeniable condition in which the chance to use well understandable language namely students' first language does exist. 
Yulianti, Atmowardoyo, Mahmud: University English Teachers .... 205

The arguments for and against the use of first language in foreign language classroom are still debatable issue. The teaching methods which adopted monolingual with target language use only and bilinguals by allowing the first language tended to keep changing for their own good.

Furthermore, the researchers came up with theories supported each side with very strong reasons. Krashen (1987) insists that students' first language should not be used in classroom in order to gain optimal exposure of the target language for comprehensible input and proficiency. On the other hand, Cook (2001) states that the first language in teaching is considered beneficial since it facilitates comprehension for conveying meanings and checking understanding. These opposite arguments also exist for the sake of real communication, learning motivation and time saving (Cook, 2001; Larsen-Freeman, 2000; Harmer, 2001; Harbord, 2001; Ellis, 2005). They seem like in vicious circle since every statement has an opponent on the other side.

As an agreement is yet to reach, the teachers are able to make their own judgment, personal believe or interpretation regarding this issue. This condition opens a chance for unprincipled language choices used in the classroom. Moreover, there is no explicit rule for language choice in foreign language teaching including higher education or university level. Therefore, the study of teachers' perception is needed to show how their judgment goes in employing the first language and target language. Going along with the teachers' perception on this issue, it is necessary to find out the students' perception, those for whom the choices made, especially English education students who take English comprehension and proficiency as important things. They have chosen English as their major and studied English for about six years since high school. The use of target language by the teachers and the students in the classroom is supposed to be more.

\section{LITERATURE REVIEW}

\section{Language Choice}

Language choice is a sociolinguistic phenomenon which refers to selecting languages for different purposes in different context (Rahman et al., 2007). In line with Rahman's, Surmi et al. (2010) states that language choice is when speakers choose what language to use in diverse social in bi or multilingual communities. Based on these definitions, it can be seen clearly that language choice exists in bilingual or multilingual communities. 


\section{6| ELT Worldwide Vol. 3 No. 2 October 2016}

The use of bilingualism as a term which refers to multilingualism or more than two languages is also stated by Mesthrie, et al. (2009:37). They prefer the term of bilingualism as the use of two or more languages in society which subsumes the idea of multilingualism. Related to education, further Findlay (1998:19) states that bilingualism also refers to bilingual education in which the practice and philosophy of teaching in two or more languages.

Language choice in language teaching and learning is selecting what language to use which involves a decision whether to use only one language or two languages. Using only one language in this case refers to monolingual with the target language while the use of two languages or bilingual means employing the students' first language and the target language. Since this research conducted in multilingual EFL Indonesian context, this research uses the terms of first language and second language as employed by Littlewood (2004: 501) in which the term second language refers to any language that is learnt when the first language system is already in place with no distinction is made between the second, third or even forth language that the person learns. Therefore, in this context the target language is English and the first language referring to the existing language known by the teacher and all of the students is Indonesian.

There are some terms under the language choice namely borrowing, code switching and code mixing. Code switching is the one so related to language teaching issue (Cook, 1991: 66). Related to codeswitching in classroom, Canagarajah (in Yletyinen, 2004) states micro-function functions of codeswitching. Micro-functions consist of classroom management and content transmission categories. For classroom management, codeswitching is considered facilitating the teachers and students to regulate classroom interactions systematically and efficiently was under scrutiny. In content transmission, codeswitching can help in the effective communication of the lesson content and language skills which have been specified in the curriculum. Classroom management functions consisted of opening the class, negotiating directions, requesting help, managing discipline, teacher encouragement, teacher compliments, teacher's commands, teacher admonitions, mitigation, pleading and unofficial interactions. Content transmission functional categories were review, definition, explanation, negotiating cultural relevance, parallel translation and unofficial student collaboration. $\mathrm{He}$ found that English was only used for material-based communication, while mother tongue was reserved for other activities. 
Yulianti, Atmowardoyo, Mahmud: University English Teachers .... 207

The definitions and the functions above make the code switching look normal in EFL classroom context if the teacher allows the use of the first language as undeniable things or strategies in teaching since he/she share or understand the same language.

\section{Classroom Interaction}

Classroom is a place in which the interaction between the teacher and the students exist. Brown (2001:170) cited interaction analysis in foreign language classroom known as FLINT system. It consists of teacher talk and student talk as follow:

\section{Teacher talk}

a) Deals with feeling which is in a non-threatening way, accepting, discussing, referring to, or communicating understanding of past, present or future feelings of the students.

b) Praise or encourage the students. It is praising, complementing, telling students why what they have said or done is valued. Jokes are also part of this point.

c) Uses ideas of students such as clarifying, using, interpreting, summarizing the idea of students. The ideas must be rephrased by the teacher but still be recognized as being student contributions.

d) Asks questions to which the answer is anticipated. This does not include rhetorical questions.

e) Gives information, fact, own opinion or idea: lecturing or asking rhetorical questions. This includes correcting without rejection.

f) Gives directions referring to giving directions, requests, or commands that students are expected to follow such as directing various drills; facilitating whole-class and small-group activity.

g) Criticizes student behavior which means rejecting the behavior of students, trying to change the non-acceptable behavior and communicating anger, displeasure, annoyance, dissatisfaction with what students are doing. This includes criticizing student response.

\section{Student Talk}

h) Student response, specific which is responding to the teacher within specific and limited range available or previously practiced answers.

i) Student response, open-ended or student-initiated which is responding to the teacher with students' own ideas, opinions, reactions, feelings.

j) Silence which is pause in the interaction. This includes silence during a piece of audiovisual equipment.

k) Confusion, work-oriented when more than one person at a time talking. This also includes confusion, non-work-oriented. 
1) Laughter

m) Uses the native language

n) Nonverbal, gestures or facial expressions

Seeing the teacher talk and student talk above, the three last points, laughter, using the native language and nonverbal are not only applied for the student but also for the teacher. Therefore, teacher takes more parts in classroom interaction. The important point here is the teacher should consider the balance of his/her talk and the student talk for effective classroom interaction.

The undeniable use of first language as a strategy in the classroom is stated by Harbord (1992).

He pointed out three categories of the teacher's objective in using L1 which were facilitating teacher-student communication, facilitating teacher-student rapport and facilitating learning. The use of L1 as a stategy was also founded by Tang (2001) in which the teacher used it to give instruction as well as explain meaning, ideas and complex grammar rules. However, Harbor did not agree with the whole parts of the first language use. Besides giving some alternatives to avoid the use of first language, he also cited Atkinston's warning about the excessive dependency of L1 use such as the students fail to realize that it is essential that they use only English in the classroom.

\section{RESEARCH METHOD}

This research investigated the university teachers' and the students' perceptions of language choice in classroom. The qualitative method was employed to this research. The data collection derived from observation, interview and documentation. The observation was nonparticipant observation in which the researcher did not directly involve in the situation being observed (Gay L. R., et al, 2006: 414).The interview was the next process to gain the data needed, researcher conducted in depth interview with semi-structure interview. The documentation was also done at the same time with the previous data collection by recording the data collection process to strengthen and ensure the data gained. Data obtained by means of observation and interview were analyzed based on Miles and Huberman (1994) concepts which classified data analysis into some steps namely data reduction, data display and conclusion. From the data collection process, the researcher moved to the analysis steps for data reduction and data display then conclusion.

This research was conducted at STKIP YPUP Makassar. The participants were two English lecturers who had got different years of teaching to enrich the data gained. The students consisted of 32 second semester English education students from four different classes in the academic year 2015/2016. 
Yulianti, Atmowardoyo, Mahmud: University English Teachers .... 209

These participants were chosen since they fitted with the purpose of this research to take English education EFL context.

\section{FINDINGS AND DISCUSSION}

Based on the objectives of this research, the data is presented into two main parts. The data was gained from observation, observation checklist and interview. The teachers' and the students' perceptions on the language choices in the classroom interaction involved role of the first language and the target language, the ideal amount of the language choices in the classroom, the lecturers' language choices plan and the existence of the language rule in the class based on the students' views. Then, these perceptions turned to be more specific to classroom interaction based on FLINT system involving teacher talk and student talk.

\section{Teachers' perceptions regarding the teacher and the students' language choices in classroom}

As stated above, the teachers' perceptions of language choices in the classroom could be stated as general and specific perceptions. The general perceptions are related to the roles of target language and first language including their advantages and disadvantages, the ideal use of language choices in the classroom, and the lecturers' language choices plan. Regarding the rule of the first language and the target language, the lecturers did realize the use of target language could make the students get accustomed. However, at the same time this target language use could lead the students to the lack of understanding which demanded the first language use.

It seems like we persuade or force in quotation to speak in English we create target language atmosphere.

(Mr. A, interviewed on 28 May 2015)

...in the class when I explain to them about the materials some of them dont understand so I use Indonesian to explain the material.

(Ms. R, interviewed on 23 May 2015)

Going further to the idea of monolingual approach, the lecturers thought it was useless so that code switching was still needed for the early semester students.

(Mr. A, interviewed on 28 May 2015)

When the level of the students are already advanced that's important to use only target language and it's helpful to improve their target language but if vice versa when the level of the students is still low and we force to use only target language ya useless. 
210| ELT Worldwide Vol. 3 No. 2 October 2016

Related to the ideal language choice in the classroom, the lecturers thought that English use in the classroom should tend to be less than Indonesian for early semester students and got bigger for the high semester students. They stated that the range $25-50 \%$ as the ideal target language use in the classroom which gave less percentage of the target language use but bigger limitation to the first language comparing to some findings in EFL classroom (Carless, 2008). Trying to keep on this thought, they stated that they planned their language use but they did not always go with the plan in the classroom. They ignored the English use plan in the classroom for students' understanding. This has to bear in mind that clear guidelines are needed by the lecturers for their language use as Ford (2009) stated that without establishing clear guidelines as to how and when L1 is used it may be difficult for a teacher to monitor not only their students' use but also their own.

Of course I plan the lesson. Yes, of course I plan [the language] with the lesson plan for example this material I will explain to them [such as] oh this part will may be difficult if I use English because I know them. I taught them in the first semester, but not very details. [However] when come to the class, I forget all the plan. I said [I] forget about English as long as they understand the material.

(Ms. R, interviewed on 23 May 2015)

Being spesific to the perceptions in classsroom interaction based on FLINT system (Brown, 2001:170), the first point of the teacher talk was dealing with feeling. The lecturers considered English as the right choice here since it is simple and easy.

I often use target language beacuse easy and the students they know how to reply.

(Mr. A, interviewed on 28 May 2015)

The same language choice was thought by the lecturers to use for praising the students. English in this talk was considered as usual thing for the students and it sounded better.

English that's usually excellent very good that's usual.

(Mr. A, interviewed on 28 May 2015)

...English it sounds excellent it will sound wow to them, if I use Indonesian it does not sound like it's not bombastic for them.

(Ms. R, interviewed on 23 May 2015)

On the other hand, part of the praising talk which is joke. It was said to be given in Indonesian for the students' understanding to make the entire students laugh. 
Yulianti, Atmowardoyo, Mahmud: University English Teachers .... $\mid 211$

Having joke in Indonesian is in the line with Harbord's (1992). However, the lecturers' perception on praising in English is away different from Cook's statement (2001) which is telling the students how well they have done in their own language is to make the praise more real.

Indonesian because I myself if I deliver joke by Indonesian they will laugh if I use English they will not understand.

(Ms. R, interviewed on 23 May 2015)

The next point of teacher talk is using the students' idea. The lecturers took Indonesian for this talk to avoid confusion and make the other students understand.

The intention of clarify is to make the others understand about the statement before I am afraid I use English and they get confused.

(Mr. A, interviewed on 28 May 2015)

Different from the previous talk, the lecturers chose English in giving questions even though one of the lecturers said that he somehow repeated the question in Indonesian. In asking question, the lecturers used English since the students would understand. However, Indonesian would be possible to use for students' understanding or for no particular reason.

I switch. I [use] English and directly translate it in Indonesian to make them understand. Even they understand, I switch. That's just my way, my favorite way, my favorite way.

(Mr. A, interviewed on 28 May 2015)

Ya, English. For example who can answer this number?, who still remember the previous lesson?

(Ms. R, interviewed on 23 May 2015)

Since asking question here was taken as related to the materials, this perception was in the line with Canagarajah's conclusion (in Yletyinen, 2004) in which the target language was used only for interaction demanded by the textbook and the lesson while the mother tongue was used for all other interactions. However, the Canangarajah's statement about target language for lesson demand was quite different from the lecturers' perceptions on giving information talk. Even though one of the lecturers tried to use English, both of them thought employing Indonesian was to make the students get the materials. This lecturers' view went along with Cook (2001) for taking the first language to facilitate comprehension.

Indonesian so the information go[es] to my students.

(Mr. A, interviewed on 28 May 2015) 


\section{$212 \mid$ ELT Worldwide Vol. 3 No. 2 October 2016}

Giving information also deals with correcting the students' mistakes. Indonesian was chosen by the lecturers to correct the mistakes to avoid the students making the same mistakes and the correction useless or even taking long time. Considering the unofficial talk, the researcher put it as another part of this talk. The lecturers decided to allow Indonesian for giving infromation related to unofficial talk to make sure the information gained. Similar to this perception, Yletyinen (2004) found this as one of the code switching functions in which the teacher gave information related to unofficial talk to the students.

Giving directions is the next talk. Although allowing Indonesian in this point was possible especially for difficult instruction, English was preferred by the lecturers since the directions were usually some similiar things or the part of teacher talk in which the lecturer could expose English to the students.

...I think [I] usually use simliar directions and I think the students get used to with the words that I use. Sometimes I am afraid they misunderstand about what I mean. If I think the instruction is difficult I switch it.

(Mr. A, interviewed on 28 May 2015)

... I have to use English as much as possible so if I use Indonesian to explain material of course the another part I have to use English.

(Ms. R, interviewed on 23 May 2015)

This lecturers' choice was different from some previous statements about the essential role of the students' native language for instruction (Tang, 2002; Auerbach, 1993; Harbord, 1992).

Indonesian was chosen for this talk to convey the lecturers' displeasure so that the students would not do the same thing. Morover, it could make the students understand the critics well.

The last point of the teacher's talk is criticizing the students' behaviour. [I] use Indonesian to emphazise so they dont do it again.

(Mr. A, interviewed on 28 May 2015)

Related to this, Cook (2001) stated the first language use to maintain the discipline in order to make the students understand and the treat is real rather than pretend. Therefore, the lecturers did think that real meaning of communication with Indonesian for criticizing the students worked here. Another part of this classroom interaction analysis is student talk consisting of students' spesific response and students' open-ended or initiated response. 
Yulianti, Atmowardoyo, Mahmud: University English Teachers .... $\mid 213$

Regarding the language choice for the students' specific response, the lecturer let the students use either English or Indonesian. Indonesian was used when the students get confused or to avoid that the students feel unfair for the lecturer speak Indonesian. However, for a task in written form or in textbook was a must to use English. Making English as the only choice for excercises in the textbooks showed how the target language became the right choice for interaction demanded by the textbook. The next student talk is students' open-ended or initiated response. The lecturers thought that Indonesian should be used here. This thought indicated the first language role in the part of students' learning activities.

These lecturers' language choices for teacher talk and student talk confirmed the same views as some previous studies. However, the differences clearly appear on the perceptions about praising the students and giving directions in which English was preferable as the ideal choice.

\section{Students' perceptions regarding the teacher and the students' language choice in classroom}

Having the sight of students for language choices is quite essential since the students are the other perticipants in the classroom and for whom the decision of the language choice is made. As the lecturers', the students' perceptions also involve general and specific perceptions of the language choices used in the classroom. The general perceptions started with the role of the target and the first language, the ideal use of the language choices in the classroom and then the rule of language choices in the classroom.

The students realized that the use of English in the classroom could contribute to the improvement of their language knowlege, skills and motivation. However, they knew that they needed Indonesian to understand and make the communication faster.

...memperlancar berbicara mungkin mengetahui banyak vocab

...to be fluent in speaking, perhaps to know a lot of vocabulary

(MJ, interviewed on 23 April, 2015)

Menurut saya Bahasa Inggris di dalam kelas merupakan motivasi untuk mengetahui Bahasa Inggris yang lebih bagus.

I think English in the classroom is motivation to know better English

(ML,interviewed on 30 April 2015)

Itumi kalau ada mahasiswa kurang mengerti.

That's when there are some students dont understand

(SS, interviewed on 23 April 2015) 


\section{4| ELT Worldwide Vol. 3 No. 2 October 2016}

Regarding the idea of monolingual approach in the classroom, they considered it important for the benefits of the target language use. Some students who did not support this idea thought that Indonesian was still needed to allow for some unknown words.

Penting kalau saya bilang penting karena orang tersebut akan termotivasi untuk belajar Bahasa Inggris kalau misalkan lecturernya menggunakan Bahasa Inggris terus mereka tidak tau mereka akan termotivasi untuk belajar

If I could say it's important because the people will be motivated to learn English if for example the lecturer uses English all the time then they dont understand, they will be motivated to learn

(RS interviewed on 29 April 2015)

I think not really (important) because they should speak English actually Indonesia only for some words that we don't understand

( $\mathrm{AB}$, interviewed on 30 April 2015)

Moving to the ideal use of English, they came with different ranges yet away bigger than the target language use stated by their lecturers thought by having more English in the classroom or at least the half of the classroom interaction with the existance of language rules. They considered it important to have the rule of either English or Indonesian in the class.

Kalau menurut saya penting karena kita kan jurusan Bahasa Inggris jadi kita harus batasi kapan kita harus mengunakan Bahasa Inggris Bahasa Indonesia

I think it's important because our major is English so we should be limited when we have to speak English or Indonesian

(SL, interviewed on 29 April 2015)

Turning to particular talk in the classroom interaction, the students' ideas were not much different from the lecturers'. The first point for the teacher talk part is dealing with feeling. The students preferred English for this talk. They seemed like have no excuse to avoid using the target language for they thought it was simple and easy.

English is easier, because we already know the meaning. Using English to ask about students' feeling is easier, we understand.

(ML, interviewed on 30 April 2015)

The next talk is praising or encouraging the students. Like for first talk, English was still preferable when they got praised by the lecturers for praising in English was more touching, impressive, convincing, professional or even cooler. Moreover, they wanted to copy or learn the expressions. 
Bahasa Inggrislah. kalau pakai Bahasa Inggris saya lebih terkesan begitu lebih menyenangkan

It must be English. if using English, I'm more impressed, it's more exciting.

(DJ, interviewed on 30 April 2015)

This perception is so different from the current belief in which the first language preferance for praising (Cook, 2001 and Sadeharju, 2012). Therefore, the researcher considered the influence of political interest issue as stated by Auerbach (1993) and Levine (2011) to the social value in the students' first language context behind some of their reasons of preferring English to Indonesian in this point. This praising talk actually involves joking as subcategory. However, the students thought that Indonesian would be better for joke. They stated that besides it made them understand the joke to laugh, it was more friendly. In order to faciliatate relationship, telling joke in the second language classroom is always a way to allow the first language use. However, Harbor (1992) offered alternative strategy for this. He suggested telling simple jokes or chatting to the students in the L2 before the lesson or during the break.

The next teacher talk is using the ideas of the students. The students thought that either the first language or the target language was used. They needed Indonesian to make all of them understand while English was possible to be used if the lecturer could make it simple.

Indonesian maybe because [it's] to explain to the others.

(RS, interviewed on 29 April 2015)

The comprehensible issue does exist for this choice and it is always related to the role of first language. The students' reason indicates that the ones who chose Indonesian wanted to understand the talk directly while those who went for English knew that the understanding was essential but at the same time they also realized that English was supposed to exist in the classroom.

The other point of teacher talk is asking questions which does not include rhetorical questions. The students preferred English because they thought that if the lecturer made it in English, they would be motivated to answer it in English. Morever, question was considered easy to understand.

Kalau untuk pertanyaan lebih bagus Bahasa Inggris kalau menggunakan Bahasa Inggris kita juga semangat menggunakan Bahasa Inggris kalau Bahasa Indonesia kita juga ikut-ikutan pakai Bahasa Indonesia. 


\section{$216 \mid$ ELT Worldwide Vol. 3 No. 2 October 2016}

For a question, it's better in English. If it's English, we get courage to use English if it's Indonesian we will follow to use Indonesian

(MIG, interviewed on 23 April 2015)

This perception goes along with the idea about how the teacher's target langauge encourages the students' to employ the target language (Harmer, 2001:132). On the other hand, some students wanted the lecturer to allow Indonesian for question either using it with the target language or fully in this first language to make them understand fast. The perception to have this kind of talk in only Indonesian especially if it is simple common question indicates that they fail to understand the important of target language use which could be the result of first language overuse.

The next perception is about giving information. The students' language choice preferance for this teacher talk varied since they wanted the materials in full English, English and Indonesian or full Indonesian. Those who wanted full English thought that they could improve their ability and get trained in it. Ellis (2005:44) stated that the more exposure to the target language students receive, the faster they will learn. On the other hand, it is something to worry about some students wanted full Indonesian. They could think that they did not really understand the materials when it is not Indonesian. Here, the lecturer needed to help the students to make them realized that instead of being told the whole meaning for full understanding, they have a chance to negotiate the meaning to strengthen their language skills and interact with the target language. Related to part of this talk, correcting the students' idea is involved. The students wanted the lecturers to use Indonesian for faster understanding.

Language choices in giving direction is the next teacher talk to see based on the students' perception. English is the choice of the students to be use by the lecturers here. They thought that besides it was something common, they felt like they already got accustomed to it.

Bahasa Inggris karena kalau instruksi itu sudah mengertilah, sudah umum

English because if it's instruction/direction, it's already known, it's common

(RR, interviewed on 22 April 2015)

Criticizing the students' behaviour is the last point of teacher talk to see. The students preferred to have this talk in Indonesian which is in the line with the common perceptions of first language role in maintaining discipline or giving repremending. 
Yulianti, Atmowardoyo, Mahmud: University English Teachers .... $\mid 217$

They thought that making it in Indonesian could make them not only understand the mistakes but also take it seriously.

Because this is problem they can speak Indonesian to make the students feel what the lecturer says, to make they feel that the lecturer angry to them.

(AB, interviewed on 30 April 2015)

The next part of the classroom interaction analysis is the language choice of the students' talk consisting of students' spesific response and students' open-ended or initiated response. For the spesific response, the students chose English as the target language to be used. It was like a must for them because the question was in English form even though they did not understand they would try to look up the dictionary. This perception did adopt the idea of target language use for textbook or lesson demand. On the other hand, for open-ended or initiated, they came up with different choices. Even though, most students prefer to make it in English, some of them said that they needed Indonesian to be allowed here either combining with the target language or saying it in full Indonesian for the condition they did not know how to say it in English or got stuck in some part. They thought Indonesian should be allowed in order to help them in exploring ideas. The role of first language in expressing selves is something difficult to avoid (Auerbach, 1993). As a whole by comparing to the related recent studies in EFL context, the students showed different perceptions on the language choices in the classroom. Tsukamoto (2010) found that the students appreciated the classes conducted in English only rather than using their first language. Furthermore, Barnes and Lock (2013) unexpectedly found that the students of all levels were not supportive of L1 use in the classroom. On the other hand, in spite of their positive statement of monolingual approach or English use only as an important thing, the students in this research considered Indonesian still needed to be used in the classroom interaction.

\section{CONCLUSION AND SUGGESTION}

The result showed that the lecturers chose to allow Indonesian with the ideal language choice was English tended to be used less than Indonesian in the classroom. They did have preferable language choices for the classroom interaction. By taking FLINT system, lecturers chose English for asking the students' feeling, praising the students, giving questions and giving directions while Indonesian for joking, using the students' idea, giving information and criticizing the students' behaviour. The lecturers thought that for the students' talk, they preferred the students to use English for answering their assignment while allowing Indonesian when they gave their ideas. 
218| ELT Worldwide Vol. 3 No. 2 October 2016

Regarding the students' perceptions, surprisingly their language choices for the classroom interaction indicated similar choices to the lecturers. However, they considered monolingual as important thing in English class yet still thought they needed Indonesian with the existence of language rule in the classroom. As a whole, they demanded more English exposure in the classroom interaction with inevitable allowance of Indonesian.

In summary, the results reveal that Indonesian as one of the language choices in EFL classroom needs to be allowed for the early semester students. This is expected to be applied in which the rule of first language use and second language use exist to avoid the unprincipled first language use of the teachers and the lack of students' language awareness while at the same time to facilitate the need of the students for more exposure of target language in the classroom.

Based on the result of this research, the researcher gives some suggestions as follows: (1) English language institution is expected to have a policy for the language choices in the classroom considering the teachers and the students' perceptions. (2) The teachers are expected to have clear guideline about their language choice to give the students more exposure to the target language and avoid unprinciple uncontrolled first language use. (3) The students should be given a chance to tell their language choice in the class based on their need and led to improve their language awareness. The next related research is suggessted to be conducted in another context with different students' ability and bigger range of teacher's teaching experiences.

\section{REFERENCES}

Auerbach, E.R. 1993. Reexamining English Only in the ESL Classroom. TESOL quarterly, (Online), Vol. 27, Issue.1, p.9-32, (http://www.tesol.org/read-and-publish/journals/tesol-quarterly, Retrieved on February $3^{\text {rd }}, 2015$ ).

Barnes, D.B. and Loc, G. 2013. Student Perceptions of Effective Foreign Language Teachers: A Quantitative Investigation from a Korean University. Australian Journal of Teacher Education, (Online), Vol. 38, Issue 2, p. 19-36, (http://www. ro.ecu.edu.au, Retrieved on August 10 ${ }^{\text {th }}$, 2014).

Brown, H.D. 2001. Teaching by Principles: An Interactive Approach to Language Pedagogy. Edition. New York: Pearson Education. 
Yulianti, Atmowardoyo, Mahmud: University English Teachers ....|219

Carless, D. 2008. Student use of the Mother Tongue in the Task-based Classroom. ELT Journal, (Online), Vol. 62 p.331-338, (http://web.edu.hku.hk/f/acadstaff/412/2008_Student-use-of-themother-tongue-in-the-task-based-classroom.pdf, Retrieved on June $\left.14^{\text {th }}, 2015\right)$.

Cook, V. 1991. Second Language Learning and Language Teaching. London: Edward Arnold.

Cook, V. 2001. Using the First Language in the Classroom. The Canadian Modern Language Review, (Online), Vol.57 p. 402-423, (http://www.eric.ed.gov/ERICWebPortal/search/detailmini.jsp?_nfpb =true\&_\&ERICExtSearch_SearchValue_0=EJ623369\&ERICExtSear ch SearchType $0=$ no\&accno=EJ623369, Retrieved on February $3^{\text {rd }}$, 2015).

Dagarin, M. 2004. Classroom Interaction and Communication Strategies in Learning English as a Foreign. Ljubljana: Birografika Bori.

Ellis, R. 2005. Instructed Second Language Acquisition : A Literature Review. Wellington: Ministry of Education.

Findlay, M.S. 1998. Language and Communication: A Cross-cultural Encyclopedia. California: ABC-CLIO, Inc.

Ford, K. 2009. Principles and Practices of L1/L2 Use in the Japanese University EFL classroom. JALT Journal, (Online), Vol.31, Issue.1, p. 63-80, (http://jalt- publications.org/files/pdfarticle/art3_5.pdf, Retrieved on January $27^{\text {th }}, 2015$ ).

Gay, L.R., Mills, G. E., Airasian, P. 2006. Educational Research: Competencies for Analysis and Application. Eighth Edition. New Jersey: Pearson Prentice Hall.

Harbord, J. 1992. The Use of the Mother Tongue in the Classroom. ELT Journal, (Online), Vol. 46, Issue October, (http://203.72.145.166/ELT/files/46-4-3.pdf, Retrieved on May 3rd, 2015).

Harmer, J. 2001. The Practice of English Language Teaching.Third Edition. Essex: Longman.

Krashen, S.D. 1987. Principles and Practice in Second Language Acquisition. London: Prentice-Hall International Ltd.

Larsen-Freeman, D. 2000. Technique and Principles in Language Teaching. Second Edition. Oxford: Oxford University Press.

Levine, G.S. 2011. Code Choice in the Language Classroom. New York: Channel View Publications Ltd.

Littlewood, W. 2004. The Handbook of Applied Linguistics: Second Language Learning. Massachusetts: Blackwell Publishing Ltd. 
220| ELT Worldwide Vol. 3 No. 2 October 2016

Mesthrie, R., Swann, J., Deumert, A., Leap, W.L. 2009. Introducing Sociolinguistics. Second Edition. Edinburgh : Edinburgh University Press.

Miles, M.B. and Huberman, A.M. 1994. Qualitative Data Analysis. Second Edition. California: SAGE Publications.

Rahman, M., Rashed, A., Chan S., et al. 2007. Language Choice in Education Domain: The Malaysian Context. (Online), (http://repo.uum.edu.my/3250, Retrieved on January $27^{\text {th }}, 2015$ ).

Surmi, M., Mahishi, R. Nataliya, R. 2010. Language Choice and Code Switching. (Online), (http://www.powershow.com, Retrieved on January $\left.27^{\text {th }}, 2015\right)$.

Tang, J. 2002. Using L1 in the English Classroom. English Teaching Forum, (Online), Vol. 40 p.36-43, (http://www.americanenglish.state.gov /files/ae/resource_files/02-40-1-h.pdf, Retrieved on June 14 $\left.{ }^{\text {th }}, 2015\right)$.

Tsukamoto, M. 2012. Students' Perception of Teachers' Language Use in an EFL Classroom. 大阪女学院大学紀要 Journal, (Online), $\quad$ Vol. $\quad 8 \quad$ p.143-154. (http://www.wilmina.ac.jp/ojc/edu/kiyo_2011, Retrieved on August $\left.10^{\text {th }}, 2014\right)$.

Yletyinen, H. 2004. The Functions of Codeswitching in EFL Classroom Discourse. (Online), (http://jyx.jyu.fi, Retrieved on January $\left.27^{\text {th }}, 2015\right)$. 